\title{
RETINOL BINDING PROTEIN 4 LEVELS RELATE TO THE PRESENCE AND SEVERITY OF CORONARY ARTERY DISEASE
}

\author{
NIVOI RETINOL VEZUJUĆEG PROTEINA 4 ODGOVARAJU PRISUSTVU I TEŽINI \\ KORONARNOG ARTERIJSKOG OBOLJENJA
}

\author{
Gokay Nar ${ }^{1}$, Sara Cetin Sanlialp ${ }^{2}$, Rukiye $\mathrm{Nar}^{3}$ \\ ${ }^{1}$ Pamukkale University, Faculty of Medicine, Department of Cardiology, Denizli, Turkey \\ ${ }^{2}$ Servergazi State Hospital, Department of Cardiology, Denizli, Turkey \\ ${ }^{3}$ Pamukkale University, Faculty of Medicine, Department of Medical Biochemistry, Denizli, Turkey
}

\section{Summary}

Background: The previous studies have showed that serum retinol binding protein 4 (RBP4) levels increase in metabolic disorders which are closely associated with cardiovascular diseases (CVD). However, the human studies investigating the role of RBP4 in CVD are conflicted. Therefore, we aimed to evaluate the relationship between RBP4 with the presence and severity of coronary artery disease (CAD) in this study.

Methods: 55 patients with presenting acute coronary syndrome (ACS) and 43 control subjects who had various cardiovascular risk factors with normal coronary artery on coronary angiography were included in this study. The serum RBP4 concentrations were measured using ELISA method, clinically and anatomically score models were used to assess the severity of coronary lesion.

Results: Serum RBP4 levels were significantly higher in patients with ACS compared to the without ACS (68.40 \pm $47.94 \mathrm{mg} / \mathrm{L}$ vs. $49.46 \pm 13.64 \mathrm{mg} / \mathrm{L} ; \mathrm{p}=0.014) . \mathrm{RBP} 4$ was correlated with GENSINI and SYNTAX I score $(r=$ $0.286 p=0.034 ; r=0.403 p=0.002$ respectively) However, there was no relationship between RBP4 and GRACE score.

Conclusions: The serum RBP4 levels increase in patients with $C A D$ and its increased levels may be correlated with CAD severity.

Keywords: Adipokine, acute coronary syndrome, retinol binding protein 4, CAD severity

Address for correspondence:

Rukiye Nar, MD, Associate professor

Pamukkale University, Faculty of Medicine, Department of

Medical Biochemistry, Çamlaraltı, Kınıklı Yerleşkesi, Üniversite

Cd. No:11, 20160 Pamukkale, Denizli/Turkey

Telephone: 02582966000-5916

e-mail: rukiyenar@hotmail.com

\begin{abstract}
Kratak sadržaj
Uvod: Predhodna ispitivanja pokazala su da su nivou serumskog vezujućeg proteina 4 (RBP4) povećani u metaboličkim poremećajima sa kardiovaskularnim oboljenjem (KVO). Međutim, može se reći da su ova izučavanja RBP4 u KVO oprečna. Iz tog razloga cilj je bio da se proceni odnos između RBP4 zavisno od pisustva i težine koronarnog arterijskog oboljenja oboljenja (KAO).

Metode: U ovo izučavanje uključeno je 55 pacijenata sa akutnim koronarnim sindromom (AKS) i 43 kontrolne osobe sa različitim kardiovaskularnim faktorima rizika sa normalnom koronarnom arterijom pri koronarnoj angiografiji. Koncentracija RBP4 merena je primenom ELISA metode, a klinički i anatomski skorovi su korišćeni za procenu težine koronarnih lezija.

Rezultati: Nivoi serumskog RBP4 bili su značajno viši kod pacijenata sa AKS u poređenju sa onima bez AKS (68,40 \pm $47,94 \mathrm{mg} / \mathrm{L}$ vs. 49,46 $\pm 13,64 \mathrm{mg} / \mathrm{L} ; \mathrm{p}=0,014)$. RBP4 je bio u korelaciji sa GENSI i SYNTAX I skorom ( $r=0,034$; $r=0,403 ; p=0,002$ ). Međutim, nije bilo odnosa između RBP4 i GRACE skora.

Zaključak: Nivoi serumskog RBP4 povećani su u pacijenata sa KAO i njihovi povećani nivoi mogu biti u korelaciji sa težinom KAO.
\end{abstract}

Ključne reči: adipokin, akutni koronarni sindrom, retinol vezujući protein 4 , težina $\mathrm{KAO}$

List of abbreviations: FPG, fasting plasma glucose; TChol, total cholesterol; TG, triglyceride; LDL-C, low-density lipoprotein cholesterol; HDL-C, high-density lipoprotein cholesterol; WBC, white blood cell; CRP, C-reactive protein; RBP4, retinol binding protein 4; LVEF, left ventricular ejection fraction; ACS, acute coronary syndrome; RBP4, retinol binding protein 4 


\section{Introduction}

Coronary artery disease (CAD) has high mortality and morbidity rate in the world and one of the main mechanisms responsible for its pathophysiology is inflammation (1). Although most of the clinical studies have shown that cytokines are an important cornerstone in the development of atherosclerosis, the studies investigating the relationship between adipokines with CAD have recently begun to find a place in the literature (2). One of the interesting adipokines is the retinol binding protein 4 (RBP4) released by mature adipocytes and active macrophages (3). RBP4 increases gluconeogenesis by stimulating phosphoenol pyruvate carboxylase and also lead to fat accumulation in visceral adipose tissue $(4,5)$.

There are many studies showing high RBP4 levels in obesity, hypertension and insulin resistance closely related with $\operatorname{CAD}(6,7)$. Recently, increased RBP4 levels were correlated with carotid intimamedia thickness and atheroma plaques circulation in patients with rheumatoid arthritis. Also another study confirmed that high RBP4 levels may indicate an increased risk of CAD in women $(8,6)$. Although it has been claimed that RBP4 may have a role in the development of subclinical atherosclerosis, its role in the progression is not clear yet. This raises the debate whether increasing levels of RBP4 in the circulation would be a predictor for CAD. Therefore, we aimed to investigate the relationship between RBP4 levels with the presence and severity of CAD identified by angiograpically and clinically risk scores in patients presenting with acute coronary syndromes (ACS) in this study.

\section{Material and Methods}

\section{Study population}

This observational case-control study was carried out with 55 consecutive patients with ACS who admitted to the emergency department of Pamukkale University Faculty of Medicine Hospital, and 43 control subjects with normal coronary artery who underwent coronary angiography between January 2018 and June 2018. Inclusion criteria were the age range of 19-90 years, performing coronary angiography due to ACS or performing coronary angiography due to positive and suspected ischemia in non-invasive stress imaging tests in patients with at least one cardiovascular risk factor such as hypertension, diabetes or smoking. Previous myocardial infarction or CAD history, cardiomyopathies, severe heart valve diseases, acute pericarditis/myocarditis, cerebrovascular diseases, malignancies, hematological diseases, acute and chronic infections, chronic inflammation, autoimmune diseases, chronic renal failure (The calculated glomerular filtration rate using CockcroftGault formula $<60 \mathrm{~mL} / \mathrm{min} / 1.73 \mathrm{~m}^{2}$ ), severe liver disease were the exclusion criteria.
The acute myocardial infarction (AMI) was diagnosed on the basis of typical symptoms of myocardial ischemia (chest discomfort or angina equivalent), newly developed ischemic ST-T changes (ST-elevation or ST-segment depression or prominent T-wave inversion) in at least 2 contiguous ECG leads and elevated cardiac-associated biomarkers of necrosis in an appropriate clinical presentation.

This study was consistent with the Helsinki declaration and was approved by the hospital's ethical review board (Pamukkale University Faculty of Medicine Hospital, Denizli, Turkey). Written informed consent form was obtained from all subjects.

\section{Data Collection}

Peripheral venous blood samples were collected after 8-12 hours fasting from all subjects. Routine biochemical parameters including fasting blood glucose, kidney function tests, lipid parameters and C-reactive protein (CRP) were analyzed with Cobas 8000 Autoanalyser (Roche Diagnostic Corp., Mannheim, Germany) and hematologic parameters were measured using Mindray BC-6800 Autoanalyser (Mindray BioMedical Electronics Co., Ltd., Shenzhen, China).

The serum concentration of RBP4 was measured using a commercially available enzyme-linked immunosorbent assay kit (YLbiont, YLA1249Hu, Shanghai YL Biotech Co., Ltd, China) in accordance with the manufacturer's instructions. Samples were diluted 2-fold into the dilution buffer provided. The detection limit of the assay was $0.26 \mathrm{mg} / \mathrm{L}$ (range: $0.5-180 \mathrm{mg} / \mathrm{L})$. All samples were assayed in duplicate. The absorbance was measured at $450 \mathrm{~nm}$ with Biotek Elx800 microplate reader (BioTek Instruments Inc., USA). The data were processed with the Gen5 Data Analysis software (BioTek Instruments Inc., USA) and RBP4 results were calculated based on the standard curve generated by using a five-parameter curve fitting equation and multiplied by the sample dilution factor.

Transthoracic echocardiography was performed with Vivid 7 GE (General Electric Vingmed Ultrasound, Horten, Norway) in the left lateral decubitus position and left ventricular morphology and functions were evaluated. The left ventricular ejection fraction was calculated by using bi-planar Simpson method.

\section{Coronary Angiography and Coronary Lesion Severity Assessment}

All patients underwent transfemoral angiography using the standard Judkins technique. Diagnostic angiograms were recorded using a digital media viewer and the records were reexamined by 2 experienced cardiologists who were blind to the study protocol. 
Global Registry of Acute Coronary Events (GRACE) score including 8 parameters (age, heart failure, systolic blood pressure, creatinine, cardiac arrest at admission, ST segment deviation on ECG, abnormal cardiac enzymes and killip class) was used for the clinical risk assessment (9). Anatomically coronary lesion severity was evaluated using SYNTAX I and GENSINI risk scores. The Gensini score was calculated by assigning a severity score to each coronary lesion according to the degree of narrowing and localization importance. The total score was equal to the sum of the stenosis score and the location score for all diseased segments (10). SYNTAX I score was calculated for stenosis diameter of $50 \%$ or greater in vessels of $1.5 \mathrm{~mm}$ or more in diameter and the latest online updated version (2.11) was used (www.syntaxscore.com) (11).

\section{Statistical analysis}

All data were analyzed using SPSS v.21.0 for Windows (SPSS, Inc., Chicago, III., USA). Categorical variables were expressed as frequencies and percentages; continuous variables were expressed as means \pm SD. The normal distribution of the data was evaluated using the Kolmogorov-Smirnov test. The vari- ables with normal distribution were compared using Student $T$ test and Mann-Whitney $U$ test was used when the normal distribution was not provided. Comparison of categorical variables was performed with chi-square test. The correlation between variables was tested via Spearman or Pearson correlation analysis and $p<0.05$ was considered as statistically significant.

\section{Results}

The demographic-clinical characteristics and other findings of the study population are summarized in Table I. The mean age and gender distribution differed among groups (66.49 \pm 12.27 years vs. $57.00 \pm 11.06$ years, $p<0.001 ; 62 \%$ (34) vs. $40 \%$, (17), $p=0.028)$. There were no differences in incidences of hypertension and diabetes, biochemical parameters including fasting blood glucose, creatinine, lipid parameters, complete blood counts and CRP ( $p>0.05)$. The serum concentration of RBP4 was higher in patients with CAD (68.40 \pm 47.94 $\mathrm{mg} / \mathrm{L}, 49.46 \pm 13.64 \mathrm{mg} / \mathrm{L} ; \mathrm{p}=0.014$ ). (Table I, Figure 1) The average GRACE, GENSINI SYNTAX I scores were calculated as $115.62 \pm 24.24,66.41 \pm$ 50.53 and $27.30 \pm 9.73$ respectively in patients with

Table I Baseline characteristics, laboratory findings and medications.

\begin{tabular}{|c|c|c|c|}
\hline Variables & ACS group $(n=55)$ & Control group $(n=43)$ & $\mathrm{p}$ \\
\hline Mean age (years) & $66.49 \pm 12.27$ & $57.00 \pm 11.06$ & $<0.001$ \\
\hline Males, n (\%) & $34(62)$ & $17(40)$ & 0.028 \\
\hline Hypertension, n (\%) & $29(53)$ & $17(40)$ & 0.194 \\
\hline Diabetes mellitus, n (\%) & $22(40)$ & $13(30)$ & 0.317 \\
\hline Smoking, n (\%) & $12(22)$ & $8(19)$ & 0.695 \\
\hline LVEF (\%) & $47.22 \pm 10.27$ & $51.19 \pm 18.08$ & 0.174 \\
\hline $\mathrm{FBG}(\mathrm{mmol} / \mathrm{L})$ & $8.48 \pm 4.06$ & $7.32 \pm 4.46$ & 0.183 \\
\hline Creatinine (mmol/L) & $85.75 \pm 29.17$ & $83.10 \pm 19.45$ & 0.661 \\
\hline TChol (mmol/L) & $4.39 \pm 0.87$ & $4.03 \pm 1.69$ & 0.182 \\
\hline LDL-C (mmol/L) & $2.59 \pm 0.79$ & $2.29 \pm 1.12$ & 0.132 \\
\hline $\mathrm{HDL}-\mathrm{C}(\mathrm{mmol} / \mathrm{L})$ & $1.05 \pm 0.25$ & $1.13 \pm 0.56$ & 0.387 \\
\hline TG $(\mathrm{mmol} / \mathrm{L})$ & $1.63 \pm 0.91$ & $1.74 \pm 1.04$ & 0.588 \\
\hline Hemoglobin $(\mathrm{g} / \mathrm{L})$ & $126.3 \pm 20.9$ & $133.0 \pm 14.6$ & 0.075 \\
\hline WBC $\left(\times 10^{9} / \mathrm{L}\right)$ & $10.55 \pm 4.15$ & $9.74 \pm 2.77$ & 0.271 \\
\hline CRP (mg/L) & $14 \pm 31.3$ & $10.2 \pm 14.5$ & 0.588 \\
\hline RBP4 (mg/L) & $68.40 \pm 47.94$ & $49.46 \pm 13.64$ & 0.014 \\
\hline GRACE score & $115.62 \pm 24.24$ & & \\
\hline GENSINI score & $66.41 \pm 50.53$ & & \\
\hline SYNTAX I score & $27.30 \pm 9.73$ & & \\
\hline
\end{tabular}




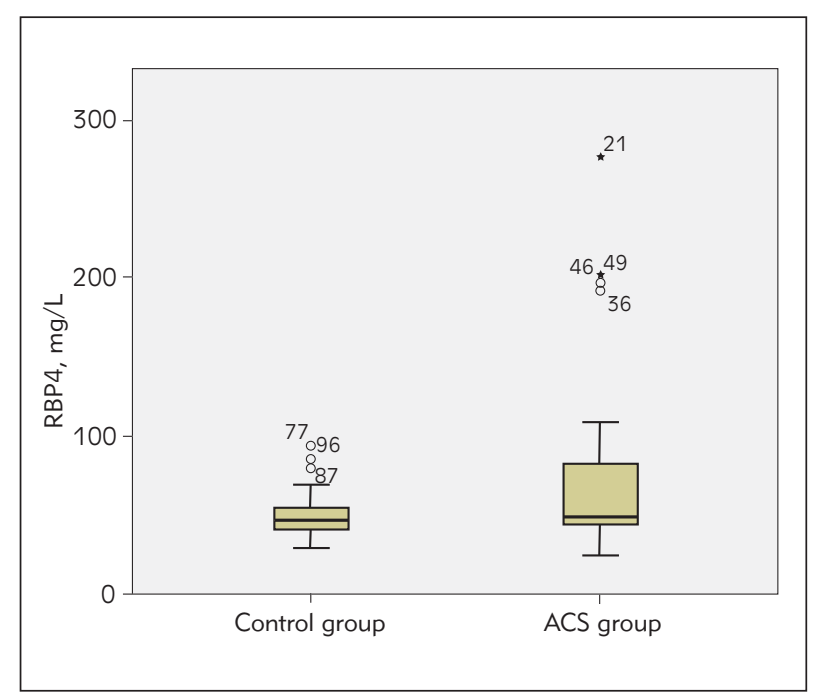

Figure 1 RBP4 concentrations in study population.

Table II The correlation analysis of RBP4 and laboratory parameters.

\begin{tabular}{|l|c|c|}
\hline \multicolumn{3}{|c|}{ RBP4 } \\
\hline Variables & $r$ & $p$ \\
\hline GENSINI & 0.286 & 0.034 \\
\hline SYNTAX I & 0.403 & 0.002 \\
\hline GRACE & 0.050 & 0.768 \\
\hline LVEF & 0.125 & 0.362 \\
\hline WBC & -0.174 & 0.205 \\
\hline Hemoglobin & 0.051 & 0.71 \\
\hline FBG & 0.081 & 0.558 \\
\hline Creatinine & -0.024 & 0.862 \\
\hline TChol & -0.015 & 0.916 \\
\hline LDL-C & 0.018 & 0.898 \\
\hline HDL-C & 0.065 & 0.637 \\
\hline TG & -0.102 & 0.457 \\
\hline CRP & -0.070 & 0.613 \\
\hline
\end{tabular}

ACS. There was a positive correlation between RBP4 with GENSINI score $(r=0,286$ and $p=0.034)$ and SYNTAX I score $(r=0.403$ and $p=0.002)$. However, it was not found any relationship between RBP4 and GRACE risk score (Table II, Figure 2-4).

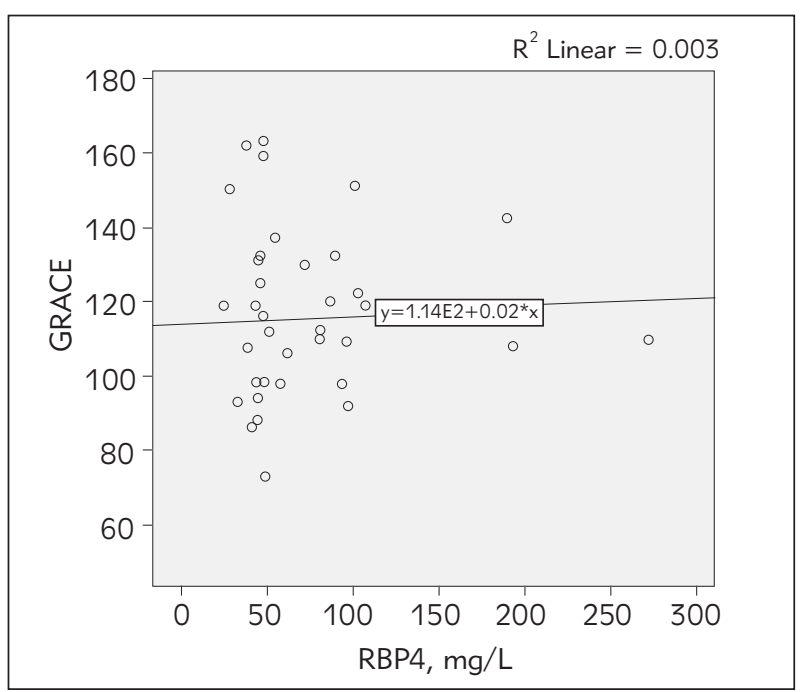

Figure 2 The correlation between RBP4 with GRACE score.

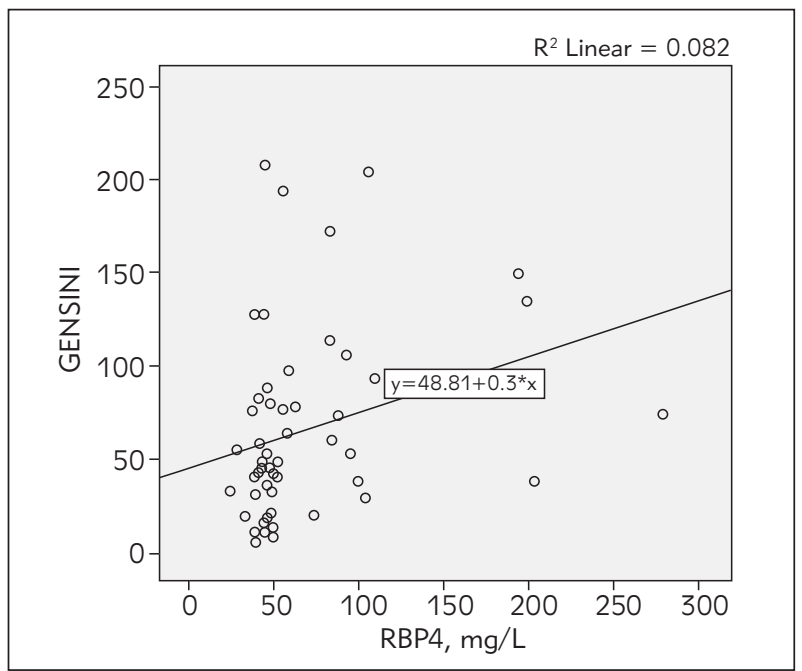

Figure 3 The correlation between RBP4 with GENSINI score.

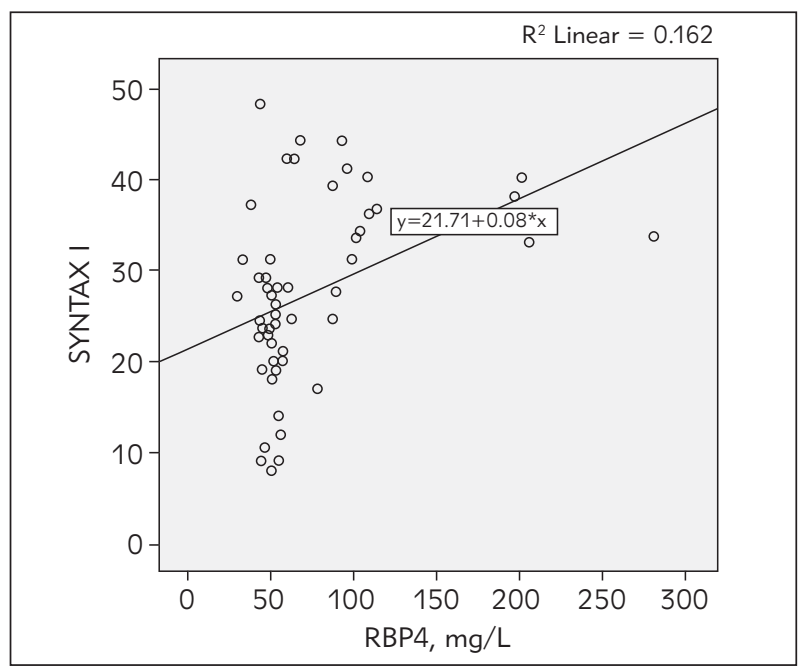

Figure 4 The correlation between RBP4 with SYNTAX I score. 


\section{Discussion}

We evaluated the role of RBP4 in determining the presence and severity of CAD in this study. We found that the serum RBP4 levels were higher in ACS patients than in controls. Also GENSINI and SYNTAX I scores showed significantly correlation with RBP4, but not GRACE score.

Atherosclerosis usually develops with chronic vascular inflammation and one of the inflammation source is cellular oxidative stress. It has been suggested that RBP4 may be associated with oxidative stress and Farjo et al. confirmed that RBP4 initiates the process by stimulating gene expression associated with endothelial inflammation $(12,13)$. But the studies investigating the role of RBP4 in vascular inflammation are conflicted (14). In a study with a Saudi female population, serum RBP4 levels were higher in patients with CAD than in diabetic patients without CAD (15). In another study, it was found $48 \%$ increased serum RBP4 concentration in female patients with CAD. Also in subgroup analysis of this study, the RBP4 levels were higher in ACS patients than in patients with stable angina pectoris and the SYNTAX score showed a positive significant correlation with RBP4 in both groups (7). However, only the female gender was included in these studies. In a study involving both genders RBP4 levels were higher in patients with both ACS and stable angina pectoris compared to patients whose CAD was ruled out by coronary angiography. Although RBP4 was associated with high GENSINI score, RBP4 levels did not differ between CAD subgroups in this study. This status was explained as that RBP levels may be more affected by the presence or progression of CAD rather than its clinical presentation (16). In our study, the increased RBP4 levels in patients with CAD and the relationship of RBP4 with GENSINI and SYNTAX I scores confirmed the results of these studies. However, we did not include patients with stable angina pectoris in our study. In addition, we did not show any correlation between RBP4 with GRACE score. It may be linked to the components of GRACE score including only clinical parameters instead of angiographical findings. Also the clinical symptoms and findings may not always overlap $C A D$ severity and clinic presentation may differ in each patient due to genetic, age, gender, presence of comorbidity, current smoking, medications and early or late admission time to emergency department. Also the high number of hemodynamically stable patients, the collection of blood samples without waiting for troponin increases in patients with STEMI may have led to a lower average GRACE score, which may have caused its association with RBP4 to disappear in this study. Indeed, in a study with NSTEMI patients, a weak correlation was found between SYNTAX I and GRACE score, and it was reported that the GRACE score may indicate significant $C A D$ disease, but it may not be appropriate to use for CAD severity assessment (17).

Unlike our study, some studies have failed to show relationship between CAD with RBP4. In Korean adults who underwent coronary angiography due to stable angina pectoris, the RBP4 level did not differ between patients with and without CAD (18). However, the mean age of the subjects in this study was lower than our study, and ACS patients were not included. Moreover, the severity of CAD was evaluated using the number of diseased vessels and the number of patients with single-vessel disease were higher and the patients had lower serum RBP4 levels in this study. Another study found that serum RBP4 levels in patients with CAD were significantly lower than non-diabetic control subjects (19). The heterogeneity of the study population, the cardiovascular risk exposure time or the methodological differences in measuring serum RBP4 levels may cause the different outcomes of the studies.

It has been shown that serum RBP4 levels increase with deterioration of renal function but we failed because of not including subjects with GFR $<60 \mathrm{~mL} / \mathrm{min} / 1.73 \mathrm{~m}^{2}$ calculated by CockcroftGault formula. It is expected that increased levels of RBP4 may affect lipid parameters that pose a risk for CVD (20). However, we did not show any relationship between lipid parameters with RBP4 in this study unlike previous studies $(21,22)$. Lack of adjustment for potential confounders, using of lipid lowering drugs, diet habits and heterogeneity in visceral fat distribution may have lead to this result. In addition, CRP which an inflammatory biomarker was not correlated with RBP4 in our study While most studies showed a positive correlation between CRP with RBP4, some studies failed to demonstrate the association between RBP4 with CRP when vitamin A status and dietary vitamin $A$ intake were ruled out $(23,24)$.

The major limitation of our study was the crosssectional design, which prevented us from inferring cause-effect relationship of RBP4 with CAD. Also we did not asses the long term clinical outcomes of increased serum RBP4 levels in ACS patients. This study had relatively small sample design and we could not rule out the effects of pharmaceutical agents on RBP4 levels because the majority of subjects with various cardiovascular risk factors were under treatment. The control group had high probability of CAD so we may not extrapolate our conclusions to healthy subjects. The groups were not matched for age and gender and this may affect serum plasma RBP 4 level. Finally, methodological differences in measuring serum RBP4 levels may change the outcomes of the studies.

Serum increased RBP4 levels may show the presence and severity of CAD. However, the large multi-center studies are needed to better determine the role of RBP4 in CAD and to evaluate its prognostic significance.

\section{Funding: None.}

\section{Conflict of interest statement}

All the authors declare that they have no conflict of interest in this work. 


\section{References}

1. Yang SS, Tang L, Ge GH, Ma JW, Qiao ZY, Hou YM, et al. Meta-analysis of the long term effects of different interventions on chronic total coronary occlusions. Eur Rev Med Pharmacol Sci 2013; 17: 1583-9. https://pubmed.ncbi.nlm.nih.gov/23832722/

2. Liu T, Han C, Sun L, Ding Z, Shi F, Wang R, et al. Association between new circulating proinflammatory and antiinflammatory adipocytokines with coronary artery disease. Coronary Artery Disease 2019; 30: 52835. https://pubmed.ncbi.nlm.nih.gov/31464731/

3. Friebe D, Neef M, Erbs S, Dittrich K, Kratzsch J, Kovacs $P$, et al. Retinol binding protein 4 (RBP4) is primarily associated with adipose tissue mass in children. Int $\mathrm{J}$ Pediatr Obes 2011; 6: 345-52. https://pubmed.ncbi. nlm.nih.gov/20950077/

4. Kotnik P, Fischer-Posovszky P, Wabitsch M. RPB4: a controversial adipokine. Eur J Endocrinol 2011;165: 70311. https://pubmed.ncbi.nlm.nih.gov/21835764/

5. Craig RL, Chu WS, Elbein SC. Retinol binding protein 4 as a candidate gene for type 2 diabetes and prediabetic intermediate trails. Mole Genet Metab 2007; 90: 33844. https://pubmed.ncbi.nlm.nih.gov/17174134/

6. Sun Q, Kiernan UA, Shi L, Phillips DA, Kahn BB, Hu $F B$, et al. Plasma retinol-binding protein 4 (RBP4) levels and risk of coronary heart disease: a prospective analysis among women in the nurses' health study. Circulation 2013; 127: 1938-47. https://pubmed. ncbi.nlm.nih.gov/23584360/

7. Liu Y, Wang D, Chen H, Xia M. Circulating retinol binding protein 4 is associated with coronary lesion severity of patients with coronary artery disease. Atherosclerosis 2015; 238: 45-51. https://pubmed.ncbi.nlm.nih.gov/ 25437889/

8. Dessein PH, Tsang L, Norton GR, Woodiwiss AJ, Solomon A. Retinol Binding Protein 4 Concentrations Relate to Enhanced Atherosclerosis in Obese Patients with Rheumatoid Arthritis. PLoS ONE 2014; 9(3): e92739. https://doi.org/10.1371/journal.pone.0092739.

9. Fox KA, Dabbous OH, Goldberg RJ, Pieper KS, Eagle KA, Van de Werf $F$, et al. Prediction of risk of death and myocardial infarction in the six months after presentation with acute coronary syndrome: prospective multinational observational study (GRACE). BMJ 2006; 333 1091. https://pubmed.ncbi.nlm.nih.gov/17032691/

10. Gensini GG. Coronary arteriography: role in myocardial revascularization. Postgrad Med 1978; 63(1): 121-8. https://pubmed.ncbi.nlm.nih.gov/637926/

11. SYNTAX working group. SYNTAX score calculator. Available at http://www.syntaxscore.com. Accessed May 20, 2012.

12. Endemann DH, Schiffrin EL. Endothelial dysfunction. J Am Soc Nephrol 2004; 15: 1983-92. https:// pubmed.ncbi.nlm.nih.gov/15284284/

13. Farjo KM, Farjo RA, Halsey S, Moiseyev G, Ma JX. Retinol-binding protein 4 induces inflammation in human endothelial cells by an NADPH oxidase- and nuclear factor kappa B-dependent and retinol-independent mechanism. Cole Cell Biol 2012; 32: 5103-15. https://pubmed.ncbi.nlm.nih.gov/23071093/
14. Zabetian-Targhi F, Mahmoudi MJ, Rezaei N, Mahmoudi M. Retinol Binding Protein 4 in Relation to Diet, Inflammation, Immunity, and Cardiovascular Diseases. Adv Nutr 2015; 6: 748-62. https://pubmed.ncbi. nlm.nih.gov/26567199/

15. Alkharfy KM, Al-Daghri NM, Vanhoutte PM, Krishnaswamy S, Xu A. Serum Retinol-Binding Protein 4 as a Marker for Cardiovascular Disease in Women. PLoS ONE 2012; 7(10): e48612. https://pubmed. ncbi.nlm.nih.gov/23119072/

16. Lambadiari V, Kadoglou NPE, Stasinos V, Maratou E, Antoniadis A, Kolokathis F, et al. Serum levels of retinolbinding protein- 4 are associated with the presence and severity of coronary artery disease. Cardiovasc Diabetol 2014 Aug 21; 13: 121. https://pubmed.ncbi.nlm. nih.gov/25142320/

17. Hammamia R, Jdidi J, Mroua F, Kallel R, Hentati M, Abid $L$, et al. Accuracy of the TIMI and GRACE scores in predicting coronary disease in patients with non-STelevation acute coronary syndrome. Revista Portuguesa de Cardiologia (English Edition) 2018; 37(1): 41-9. https://pubmed.ncbi.nlm.nih.gov/29361323/

18. Kim JH, Rhee EJ, Choi ES, Won JC, Park CY, Lee WY, et al. The Relationship between Serum Retinol-Binding Protein 4 Levels and Coronary Artery Disease in Korean Adults. Korean Diabetes J 2009; 33: 105-12.

19. von Eynatten M, Lepper PM, Liu D, Lang K, Baumann M, Nawroth PP, et al. Retinol-binding protein 4 is associated with components of the metabolic syndrome, but not with insulin resistance, in men with type 2 diabetes or coronary artery disease. Diabetologia 2007; 50: 1930-7. https://pubmed.ncbi.nlm.nih.gov/17639305/

20. Ingelsson E, Sundstrom J, Melhus H, Michaëlsson K, Berne C, Vasan RS, et al. Circulating retinol-binding protein 4, cardiovascular risk factors and prevalent cardiovascular disease in elderly. Atherosclerosis 2009; 206: 239-44. https://pubmed.ncbi.nlm.nih.gov/19339013/

21. Von Eynatten $M$, Humpert PM. Retinol-binding protein4 in experimental and clinical metabolic disease. Expert Rev Mol Diagn 2008; 8: 289-99. https://pubmed. ncbi.nlm.nih.gov/18598108/

22. Graham TE, Yang Q, Bluher M, Aryal P, Ter Horst KW, Cakir $\mathrm{H}$, et al. Retinol-binding protein 4 and insulin resistance in lean, obese, and diabetic subjects. $N$ Engl J Med 2006; 354: 2552-63. https://pubmed.ncbi. nlm.nih.gov/16775236/

23. Balagopal P, Graham TE, Kahn BB, Altomare A, Funanage V, George D. Reduction of elevated serum retinol binding protein in obese children by lifestyle intervention: association with subclinical inflammation. J Clin Endocrinol Metab 2007; 92: 1971-4. https://pubmed.ncbi.nlm.nih.gov/17341558/

24. Aigner E, Bachofner N, Klein K, De Geyter C, Hohla F, Patsch W, et al. Retinol-binding protein 4 in polycystic ovary syndrome-association with steroid hormones and response to pioglitazone treatment. J Clin Endocrinol Metab 2009; 94: 1229-35. https://pubmed.ncbi. nlm.nih.gov/19158194/ 